\title{
HARMONISASI DAN SINKRONISASI PENGATURAN KELEMBAGAAN SERTIFIKASI HALAL TERKAIT PERLINDUNGAN KONSUMEN MUSLIM INDONESIA*
}

\author{
Susilowati Suparto $^{* * *}$, Djanurdi $^{* * *}$, Deviana Yuanitasari ${ }^{* * * *}$, Agus Suwandono ${ }^{* * * * *}$ \\ Departemen Hukum Perdata, Fakultas Hukum Universitas Padjajaran, Bandung \\ Jalan Dipati Ukur Nomor 35 Bandung, Jawa Barat, 40132
}

\begin{abstract}
The application of Halal Product Guarantee act (UUJPH) have an impact on institutional changes related to the execution of halal certification. The role of of Halal Certification administration and execution will be transferred from LPPOM-MUI to BPJPH. Since BPJPH is a new organisation and yet established, LPPOMMUI still responsible during the transition phase. During the LPPOM-MUI tenure, the legal enforcement of Halal certification was uncertain, because the voluntary nature of LPPOM-MUI membership. In the long run, BPJPH will coordinate with MUI and LPH for the implementation of Halal Certification. To ensure the successful implementation of Halal Product Warranty, BPJPH need to synergize its role and function with related ministries and agencies.
\end{abstract}

Keywords: regulation, institutional, halal certification, consumer.

\section{Intisari}

Pemberlakuan UUJPH membawa perubahan terkait kelembagaan penyelenggaraan sertifikasi halal. Penyelenggaraan sertifikasi halal yang selama ini dilaksanakan oleh LPPOM-MUI akan dialihkan ke BPJPH. Selama BPJPH belum terbentuk sertifikasi halal tetap dilaksanakan oleh LPPOM-MUI. Praktik penyelenggaran sertifikasi halal oleh LPOM-MUI bersifat sukarela, sehingga belum memberikan jaminan kepastian hukum. BPJPH dalam pelaksanaan sertifikasi halal bekerjasama dengan MUI dan LPH. BPJPH dalam penyelenggaraan jaminan produk halal perlu mensinergikan kewenangan yang dimilikinya dengan tugas, fungsi dan kewenangan kementerian dan lembaga terkait.

Kata Kunci: pengaturan, kelembagaan, sertifikasi halal, konsumen.

\section{Pokok Muatan}

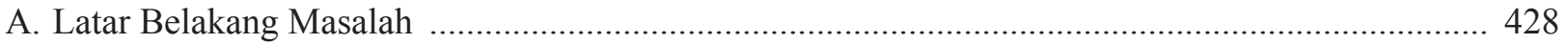

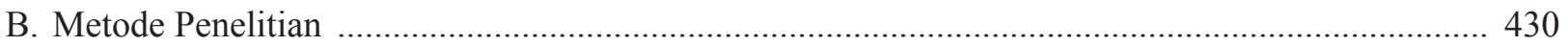

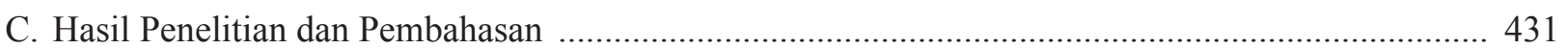

1. Praktik Penyelenggaraan Sertifikasi Halal di Indonesia Terkait Undang-Undang Nomor 33 Tahun 2014 tentang Jaminan Produk Halal

2. Konsep Badan Penyelenggara Jaminan Produk Halal (BPJH) dalam Penyelenggaraan Sertifikasi Halal di Indonesia

D. Kesimpulan

\footnotetext{
Penelitian ini merupakan Penelitian Unggulan Perguruan Tinggi Universitas Padjajaran Bandung Tahun 2005.

Correspondence address: susilowati.suparto@yahoo.com.

**** Correspondence adress : djanuardi@unpad.ac.id.

***** Correspondence adress : devianayuanitasari@yahoo.com.

****** Correspondence adress : agus.suwandono@unpad.ac.id.
} 


\section{A. Latar Belakang Masalah}

Undang-Undang No. 8 Tahun 1999 Tentang Perlindungan Konsumen (UUPK) merupakan payung hukum pelaksanaan perlindungan konsumen di Indonesia. ${ }^{1}$ Perlindungan konsumen adalah segala upaya yang menjamin adanya kepastian hukum untuk memberi perlindungan kepada konsumen. ${ }^{2}$ Perlindungan hukum terhadap konsumen pada dasarnya merupakan perlindungan terhadap pemenuhan atas hak-hak konsumen yang seharusnya diberikan kepada konsumen, ${ }^{3}$ sehingga perlindungan konsumen sesungguhnya identik dengan perlindungan yang diberikan hukum terhadap hak-hak konsumen. ${ }^{4}$

UUPK telah mengatur mengenai hakkonsumen. Salah satu hak konsumen yakni yang diatur dalam Pasal 4 huruf a UUPK yang menentukan bahwa konsumen memiliki hak atas kenyamanan, keamanan dan keselamatan dalam mengkonsumsi barang dan/atau jasa. Bagi konsumen muslim, salah satu kenyamanan konsumen dalam menggunakan produk ialah adanya jaminan halal dari pelaku usaha. Hal ini senantiasa berkaitan dengan keyakinan agamanya untuk selalu menggunakan dan mengkonsumsi produk halal.

UUPK dalam rangka perlindungan terhadap konsumen muslim terkait dengan kehalalan suatu produk sebenarnya telah mengaturnya dalam Pasal 8 UUPK mengenai perbuatan yang dilarang bagi pelaku usaha. Pasal 8 ayat (1) huruf h menyatakan bahwa pelaku usaha dilarang memproduksi dan/ atau memperdagangkan barang dan/atau jasa yang tidak mengikuti ketentuan berproduksi secara halal sebagaimana pernyataan halal yang dicantumkan dalam label. UUPK dalam hal ini tidak mewajibkan kepada pelaku usaha untuk melakukan sertifikasi halal terhadap produknya, namun jika pelaku usaha telah mencantukan label halal dalam produknya maka pelaku usaha harus mengikuti ketentuan berproduksi secara halal.

Pengaturan pemeriksaan sertifikasi halal pada awalnya merupakan kewenangan dari Kementerian Agama. ${ }^{5}$ Kementerian Agama telah mengeluarkan Keputusan Menteri Agama No. 518 Tahun 2001 Tentang Pedoman dan Tata Cara Pemeriksaan dan Penetapan Pangan Halal. Selanjutnya ditindaklanjuti dengan Keputusan Menteri Agama No. 519 Tahun 2001 Tentang Lembaga Pelaksana Pemeriksa Pangan Halal, yang menunjuk dan mendelegasasikan pelaksanaan sertifikasi halal ke Lembaga Pengkajian Pangan Obat Obatan dan Kosmetika - Majelis Ulama Indonesia (LPPOMMUI).

Dalam perkembangnya, pengaturan sertifikasi halal selama ini masih terkesan sektoral, parsial, inkonsistensi serta tidak sistemik dan sukarela (voluntary), yang mengakibatkan sertifikasi halal belum mempunyai legitimasi hukum yang kuat. ${ }^{6}$ Selain itu masih banyaknya produk yang beredar di masyarakat belum semua terjamin kehalalannya, sehingga memerlukan pengaturan yang komprehensif yang meliputi produk barang dan jasa. ${ }^{7}$ Berdasarkan alasan tersebut maka penyelenggaraan sertifikasi halal kemudian diatur secara khusus dalam Undang-Undang No. 33 Tahun 2014 Tentang Jaminan Produk Halal (UUPJH).

Pemberlakuan UUJPH merupakan salah satu bentuk perlindungan dari negara kepada konsumen muslim di Indonesia. Hal ini sesuai dengan Pasal 29 ayat (2) UUD 1945 mengamanatkan bahwa negara

\footnotetext{
Penjelesan Umum Undang-Undang No. 8 Tahun 1999 Tentang Perlindungan Konsumen (Lembaran Negara Republik Indonesia Tahun 1999 Nomor 42, Tambahan Lembaran Negara Republik Indonesia Nomor 3821).

Pasal 1 ayat (1) Undang-Undang No. 8 Tahun 1999 Tentang Perlindungan Konsumen (Lembaran Negara Republik Indonesia Tahun 1999 Nomor 42, Tambahan Lembaran Negara Republik Indonesia Nomor 3821).

Janus Sidabalok, 2006, Hukum Perlindungan Konsumen di Indonesia, Citra Aditya Bakti, Bandung, hlm. 10.

Shidarta, 2004, Hukum Perlindungan Konsumen, Gramedia, Jakarta, hlm. 19.

Pasal 11 ayat (2) Peraturan Pemerintah No. 69 Tahun 1999 tentang Label dan Iklan Pangan (Lembaran Negara Republik Indonesia Tahun 1999 Nomor 131, Tambahan Lembaran Negara Republik Indonesia Nomor 3867).

KN. Sofyan Hasan, "Kepastian Hukum Sertifikasi dan Labelisasi Halal Produk Pangan”, Dinamika Hukum, Vol. 14, No. 2, Mei 2014, hlm. 227.

Penjelasan Umum Undang-Undang No. 33 Tahun 2014 tentang Jaminan Produk Halal (Lembaran Negara Republik Indonesia Tahun 2014 Nomor 295, Tambahan Lembaran Negara Republik Indonesia Nomor 5604).
} 
menjamin kemerdekaan tiap-tiap penduduk untuk memeluk agamanya masing-masing dan untuk beribadah menurut agamanya dan kepercayaannya. Untuk menjamin setiap pemeluk agama untuk beribadah dan menjalankan ajaran agamanya, negara berkewajiban memberikan pelindungan dan jaminan tentang kehalalan produk yang dikonsumsi dan digunakan masyarakat, khususnya masyarakat muslim. ${ }^{8}$

Pasal 1 angka 5 UUJPH menyatakan bahwa jaminan produk halal adalah kepastian hukum terhadap kehalalan suatu produk yang dibuktikan dengan sertifikat halal. ${ }^{9}$ Obyek sertifikasi halal yang diatur dalam UUJPH lebih luas tidak hanya berupa terkait dengan produk pangan. Hal ini dapat dilihat dari ketentuan Pasal 1 angka 1 UUPJH yang menyatakan bahwa produk yang disertifikasi meliputi barang dan/atau jasa yang terkait dengan makanan, minuman, obat, kosmetik, produk kimiawi, produk biologi, produk rekayasa genetik, serta barang gunaan yang dipakai, digunakan, atau dimanfaatkan oleh masyarakat. ${ }^{10}$

Berdasarkan Pasal 5 UUJPH penyelenggaraan jaminan produk halal merupakan tanggung jawab pemerintah, ${ }^{11}$ dalam hal ini dilaksanakan oleh Kementerian Agama. ${ }^{12}$ Untuk melaksanakan penyelenggaraan jaminan produk halal tersebut pemerintah akan membentuk Badan Penyelenggara Jaminan Produk Halal (BPJPH) yang berkedudukan di bawah dan bertanggung jawab kepada Menteri Agama.

BPJPH dalam penyelenggaraan jaminan produk halal diberikan kewenangan untuk menerbitkan dan mencabut sertifat halal dan label halal pada produk. Kewenangan ini sebelumnya dilaksanakan oleh LPPOM-MUI. Dengan pemberlakuan UUJPH ini secara kelembagaan, nantinya akan terjadi peralihan kewenangan dalam penerbitan sertifikasi halal dari LPPOM-MUI kepada BPJPH. Sertifikat halal merupakan pengakuan kehalalan suatu produk yang dikeluarkan oleh BPJPH berdasarkan fatwa halal tertulis yang dikeluarkan oleh MUI.

BPJPH sendiri sampai saat ini belum terbentuk, karena UUJPH menentukan bahwa BPJPH ini harus dapat berdiri paling lambat tiga tahun semenjak diundangkannya UUJPH. Hal ini sesuai Pasal 64 UUJPH yang mengamanatkan bahwa pembentukan BPJPH dibentuk paling lambat 3 (tiga) tahun sejak UUJPH diundangkan, yakni 17 Oktober 2017.

Pembentukan BPJPH harus dapat dilihat dalam kerangka sistem hukum perlindungan konsumen. Hukum perlindungan konsumen merupakan keseluruhan asas-asas dan kaidah-kaidah yang mengatur dan melindungi konsumen dalam hubungan dan masalah penyediaan dan penggunaan produk konsumen antara penyedia dan penggunanya, dalam kehidupan bermasyarakat. ${ }^{13}$ Keseluruhan asas-asas dan kaidah-kaidah ini tersebar dalam beberapa peraturan perundang-undangan bukan hanya yang terdapat dalam UUPK maupun UUJPH.

Pembentukan BPJPH sebagai upaya perlindungan terhadap konsumen juga harus dilihat sebagai suatu sistem. Hukum sebagai suatu sistem merupakan suatu tatanan atau kesatuan yang terdiri dari bagian-bagian atau unsur-unsur yang saling berkaitan, saling beriteraksi satu sama lain, yang terorganisasi dan bekerjasama untuk mencapai tujuan kesatuan itu. ${ }^{14}$ Hukum bukanlah sekedar sekumpulan hukum yang masing-masing berdiri

Pasal 1 angka 5 Undang-Undang No. 33 Tahun 2014 tentang Jaminan Produk Halal (Lembaran Negara Republik Indonesia Tahun 2014 Nomor 295, Tambahan Lembaran Negara Republik Indonesia Nomor 5604).

10 Pasal 1 angka 1 Undang-Undang No. 33 Tahun 2014 tentang Jaminan Produk Halal (Lembaran Negara Republik Indonesia Tahun 2014 Nomor 295, Tambahan Lembaran Negara Republik Indonesia Nomor 5604).

11 Pasal 5 ayat (1) Undang-Undang No. 33 Tahun 2014 tentang Jaminan Produk Halal (Lembaran Negara Republik Indonesia Tahun 2014 Nomor 295, Tambahan Lembaran Negara Republik Indonesia Nomor 5604).

12 Pasal 5 ayat (2) Undang-Undang No. 33 Tahun 2014 tentang Jaminan Produk Halal (Lembaran Negara Republik Indonesia Tahun 2014 Nomor 295, Tambahan Lembaran Negara Republik Indonesia Nomor 5604).

Shidarta, Op. cit., hlm. 11.

14 Sudikno Mertokusumo, 2006, Penemuan Hukum : Sebuah Pengantar, Liberty, Yogyakarta, hlm. 18. 
sendiri, tetapi hukum harus dilihat dalam kaitannya dengan bagian-bagian lain dalam sistem tersebut. ${ }^{15}$

Peraturan perundang-undangan yang terkait dengan sertifikasi halal ini diatur dalam beberapa ketentuan perundang-undangan sehingga dalam rangka pembentukan BPJPH perlujuga dilaksanakan harnonisasi dan sinkronisasi dengan peraturan perundang-undangan terkait. Harmonisasi peraturan perundang-undangan merupakan suatu proses mencari kesesuaian antara peraturan perundangundangan. Harmonisasi ini idealnya dilakukan pada saat perancangan peraturan perundang-undangan. ${ }^{16}$ Adapun sinkronisasi merupakan penyelarasan dan penyelerasian berbagai peraturan perundangundangan yang terkait dengan peraturan perundangundangan yang telah ada dan yang sedang disusun yang mengatur suatu bidang tertentu. ${ }^{17}$ Sinkronisasi dilaksanakan agar substansi yang diatur dalam produk perundang-undangan tidak tumpang tindih, saling melengkapi (suplementer), saling terkait, dan semakin rendah jenis pengaturannya maka semakin detail dan operasional materi muatannya. ${ }^{18}$ Sinkronisasi dilaksanakan meliputi sinkronisasi vertikal yakni mengidentifikasi apakah suatu perundang-undangan tersebut sejalan apabila ditinjau dari sudut strata atau hierarki peraturan perundangan yang ada, dan sinkronisasi horisontal yakni mengidentifikasi peraturan perundangundangan yang kedudukannya sederajat dan yang mengatur bidang yang sama. ${ }^{19}$

Penyelenggaraan sertifikasi halal yang selama ini telah dilaksanakan oleh LPPOM-MUI dilaksanakan kerjasama dengan kementerian dan lembaga terkait. ${ }^{20}$ Sehingga dalam rangka pembentukan BPJPH juga perlu dikaji terkait dengan tugas, fungsi dan kewenangan dari kementerian dan lembaga terkait dengan penyelenggaraan jaminan produk halal. Hal ini diperlukan agar terjadinya sinergisitas serta tidak terjadinya tumpang tindih kewenangan antara kementerian dan lembaga terkait dengan BPJPH berkaitan dengan penyelenggaran jaminan produk halal. Berdasarkan uraian di atas permasalahan yang diambil yakni bagaimanakah praktik penyelenggaraan sertifikasi halal di Indonesia terkait Undang-Undang No. 33 Tahun 2014 Tentang Jaminan Produk Halal (UUJPH) serta bagaimanakah konsep Badan Penyelenggara Jaminan Produk Halal (BPJH) dalam penyelenggaraan sertifikasi halal di Indonesia.

\section{B. Metode Penelitian}

Metode penelitian yang digunakan merupakan yuridis normatif, yang meliputi penelitian inventarisasi hukum positif, penelitian terhadap asas-asas hukum dan penelitian hukum in concreto, penelitian sistematik hukum, penelitian sejarah hukum dan perbandingan hukum. ${ }^{21}$ Data yang digunakan merupakan data sekunder berupa bahanbahan hukum primer, bahan hukum sekunder dan bahan hukum tersier. ${ }^{22}$ Penelitian ini bersifat deskriptif analitis, yaitu membuat pencaindraan secara sistematis mengenai fakta-fakta ${ }^{23}$ termasuk di dalamnya menggambarkan peraturan-peraturan yang berlaku. ${ }^{24}$

Ibid., hlm. 19

AA. Oka Mahendra, "Harmonisasi Peraturan Perundang-undangan", http://ditjenpp.kemenkumham.go.id/htn-dan-puu/421-harmonisasiperaturan-perundang-undangan.html, diakses 14 Agustus 2015.

7 Novianto M. Hantoro, "Sinkronisasi dan Harmonisasi Pengaturan Mengenai Peraturan Daerah, Serta Uji Materi Peraturan Daerah Provinsi Bali Nomor 16 Tahun 2009 Tentang Rencana Tata Ruang Wilayah Provinsi Bali Tahun 2009-2029”, http://perpustakaan.bappenas.go.id/ lontar/file?file $=$ digital/130881-\%5B_Konten_\%5D-Konten\%20C9218.pdf, diakses 21 September 2015.

8 Ibid.

19 Zaidah Nur Rosidah, "Sinkronisasi Peraturan Perundang-Undangan Mengenai Perkawinan Beda Agama”, Al-Ahkam, Vol. 23, Nomor 1, April, 2013, hlm. 6-7.

20 Majelis Ulama Indonesia, “Tentang LPPOM-MUI”, http://www.halalmui.org/muil4/index.php/main/go to section/2/31/page/1, diakses 15 Mei 2015.

Ronny Hanitijo Soemitro, 1990, Metodologi Penelitian Hukum dan Jurimetri, Ghalia Indonesia, Jakarta, hlm. 9-10.

Soerjono Soekanto, et al., 2006, Penelitian Hukum Normatif suatu Tinjauan Singkat, Rajawali, Jakarta, hlm. 13-14.

Ronny Hanitijo Soemitro, Op. cit., hlm. 22

Sumadi, 1988, Metode Penelitian, Rajawali, Jakarta, hlm. 19 


\section{Hasil Penelitian dan Pembahasan}

1. Praktik Penyelenggaraan Sertifikasi Halal di Indonesia Terkait Undang-Undang Nomor 33 Tahun 2014 tentang Jaminan Produk Halal

Penyelenggaraan jaminan produk halal di Indonesia saat ini telah diatur dalam UndangUndang No. 33 Tahun 2014 Tentang Jaminan Produk Halal (UUJPH). Pemberlakuan UUJPH ini nantinya akan membawa perubahan mendasar terkait penyelenggaraan sertifikasi halal di Indonesia. Dengan pemberlakuan UUJPH ini penyelenggaraan sertifikasi halal yang sebelumnya dilaksanakan oleh LPPOM-MUI akan diambil alih oleh BPJPH. BPJPH ini merupakan badan yang akan dibentuk oleh pemerintah untuk menyelenggarakan jaminan produk halal di Indonesia.

UUJPH sendiri telah menganatkan pembentukan Badan Penyelenggaran Jaminan Produk Halal (BPJPH) sebagai badan yang diberikan kewenangan untuk melakukan sertifikasi halal di Indonosia, menggantikan LPPOM-MUI. Namun demikian sampai saat ini BPJPH belum terbentuk, sehingga berdasarkan ketentuan Pasal 60 UUJPH bahwa sebelum BPJPH terbentuk pelaksanaan sertifikasi halal tetap dijalankan oleh MUI dalam hal ini LPPOM-MUI.

Pada awalnya pembentukan LPPOMMUI didasarkan atas mandat dari Pemerintah/ negara agar Majelis Ulama Indonesia (MUI) berperan aktif dalam meredakan kasus lemak babi di Indonesia pada tahun 1988. LPPOM MUI didirikan pada tanggal 6 Januari 1989 untuk melakukan pemeriksaan dan sertifikasi halal. Untuk memperkuat posisi LPPOM-MUI menjalankan fungsi sertifikasi halal, maka pada tahun 1996 ditandatangani Nota Kesepakatan Kerjasama antara Departemen Agama, Departemen Kesehatan dan MUI. Nota kesepakatan tersebut kemudian disusul dengan penerbitan Keputusan Menteri Agama No. 518 Tahun 2001 tentang Pedoman dan Tata Cara Pemeriksaan dan Penetapan Pangan Halal dan Keputusan Menteri Agama No. 519 Tahun 2001 tentang Lembaga Pelaksana Pemeriksa Pangan Halal, yang menguatkan kedudukan LPPOMMUI sebagai lembaga sertifikasi halal serta melakukan pemeriksaan/audit, penetapan fatwa dan menerbitkan sertifikat halal. ${ }^{25}$

Sertifikasi halal yang dilaksanakan oleh Majelis Ulama Indonesia (MUI) berupa sertifikat halal MUI yakni fatwa tertulis Majelis Ulama Indonesia yang menyatakan kehalalan suatu produk yang sesuai dengan syari'at Islam. Sertifikat Halal MUI ini merupakan syarat untuk mendapatkan ijin pencantuman label halal pada kemasan produk dari instansi pemerintah yang berwenang.

Sertifikasi halal MUI ditujukan pada produk pangan, obat-obatan, kosmetika dan produk lainnya untuk memberikan kepastian status kehalalan, sehingga dapat mentremtamkan batin konsumen dalam mengkonsumsinya. ${ }^{26}$ Jika dikaitkan dengan produk yang terdiri dari barang dan jasa, maka sertifikasi halal yang dilaksanakan oleh MUI terbatas pada kategori barang yang dapat berupa pangan, obat-obatan, kosmetika, dll. Hal ini tentunya belum dapat memberikan perlindungan seluruhnya kepada konsumen muslim. Saat ini belum adanya sertifikasi halal yang berkaitan dengan produk yang berupa jasa antara lain terkait dengan pariwisata, hotel dan restoran yang ada di Jepang. ${ }^{27} \mathrm{Hal}$ ini yang diperluas oleh UUJPH dengan memperluas obyek sertifikasi halal tidak hanya berupa produk barang tetapi juga produk jasa sebagaimana disebutkan dalam Pasal 1 angka (1) UUJPH.

LPPOM-MUI dalam proses dan pelaksanaan sertifikasi halal melakukan kerjasama dengan beberapa kementerian dan lembaga. Kerjasama tersebut antara lain dilaksanakan dengan Badan 
Pengawasan Obat dan Makanan (Badan POM), Kementerian Agama, Kementerian Pertanian, Kementerian Koperasi dan UKM, Kementerian Perdagangan, Kementerian Perindustrian, Kementerian Kelautan dan Perikanan, Kementerian Pariwisata dan Ekonomi Kreatif, Badan Standarisasi Nasional (BSN) serta Perguruan Tinggi. ${ }^{28}$ Bentuk kerjasama penyelenggaraan jaminan produk halal oleh BPJH juga diadakan kerjasama dengan pihak lain yakni MUI sebagai pihak yang menetaokan fatwa kehalalan produk, serta Lembaga Pemeriksa Halal sebagai pihak yang melakukan pemeriksaan dan pengujian terhadap kehalalan suatu produk.

Sifat pengaturan terkait dengan kewajiban sertifikasi halal sifatnya sukarela. ${ }^{29}$ Hal ini dapat dilihat dari ketentuan Pasal 10 ayat (1) Peraturan Pemerintah No. 69 Tahun 1999 tentang Label dan Iklan Pangan yang menyatakan bahwa setiap orang yang memproduksi atau memasukkan pangan yang dikemas ke Indonesia dan menyatakan pangan tersebut halal wajib bertanggung jawab atas kebenaran pernyataan dan wajib mencatumkan keteragan atau tulisan halal. Selanjutny berdasarkan Pasal 11 ayat (1) Peraturan Pemerintah No. 69 Tahun 1999 Tentang Label dan Iklan Pangan menentukan bahwa untuk mendukung kebenaran pernyataan halal tersebut, wajib untuk memeriksakan terlebih dahulu pangan tersebut pada lembaga pemeriksa yang telah diakreditasi. Berdasarkan aturan ini dapat disimpulkan bahwa sertifikasi halal baru diwajibkan apabila pelaku usaha mencantumkan label halal dalam kemasan produknya, sehingga jika pelaku usaha tidak mencantumkan label halal maka tidak wajib untuk dilakukan pemeriksaan atau sertifikasi halal. Hal ini tentunya belum memberikan kepastian hukum jaminan halal bagi konsumen muslim, karena sertifikasi halal tergantung kepada itikad baik dari pelaku usaha. Pengaturan ini tentunya berbeda dengan pengaturan dalam Pasal
4 UUJPH yang menentukan produk yang masuk, beredar, dan diperdagangkan di wilayah Indonesia wajib bersertifikat halal.

Proses sertifikasi halal yang dilakukan di MUI, pada dasarnya dilaksanakan oleh LPOMMUI. Proses sertifikasi halal, mulai pendaftaran, pemeriksaan dan pengujian produk sampai dengan penerbitan sertifikat halal suatu produk menjadi kewenangan LPPOM-MUI.

\section{Diagram 1. Alur Proses Sertifikasi Halal LPPOM-MUI}

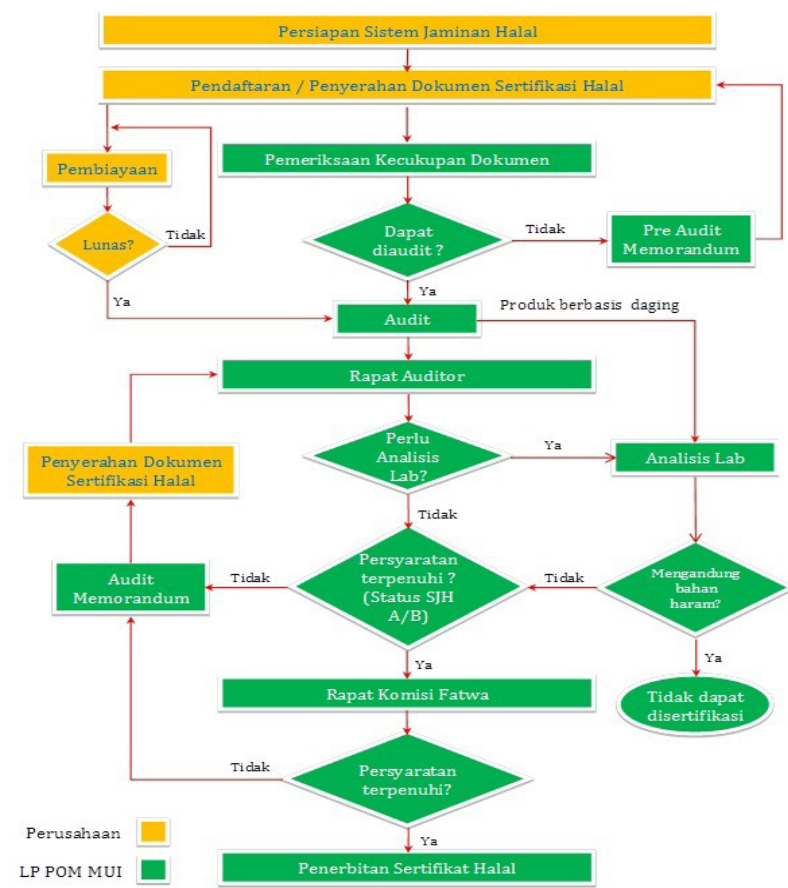

Sumber : MUI, 2015.

Secara umum prosedur sertifikasi halal adalah sebagai berikut $:^{31}$

1. Perusahaan yang mengajukan sertifikasi, baik pendaftaran baru, pengembangan (produk/fasilitas) dan perpanjangan, dapat melakukan pendaftaran secara online. melalui website LPPOM-MUI.

\footnotetext{
28 Majelis Ulama Indonesia, Tentang LPPOM-MUI",http://www.halalmui.org/mui14/index.php/main/go_to_section/2/31/page/1 diakses 15 Mei 2015.

29 KN. Sofyan Hasan, Loc.cit

30 Majelis Ulama Indonesia, "Persyaratan Sertifikasi Halal MUI”, http://www.halalmui.org/mui14/index.php/main/go to section/58/1366/ page/1 diakses 15 Mei 2015.

31 Ibid
} 
2. Mengisi data pendaftaran: status sertifikasi (baru/pengembangan/perpanjangan), data sertifikat halal, status Sistem Jaminan Halal (jika ada) dan kelompok produk.

3. Membayar biaya pendaftaran dan biaya akad sertifikasi halal.

4. Mengisi dokumen yang dipersyaratkan dalam proses pendaftaran sesuai dengan status pendaftaran (baru/ pengembangan/perpanjangan) dan proses bisnis (industri pengolahan, $\mathrm{RPH}$, restoran, dan industri jasa), diantaranya: Manual Sistem Jaminan Halal, diagram alir proses produksi, data pabrik, data produk, data bahan dan dokumen bahan yang digunakan, serta data matrix produk.

5. Setelah selesai mengisi dokumen yang dipersyaratkan, maka tahap selanjutnya sesuai dengan diagram alir proses sertifikasi halal seperti diatas yaitu pemeriksaan kecukupan dokumen.

Setelah penerbitan sertifakat halal, maka sertifikat halal yang diperoleh dari LPPOM-MUI berlaku selama 2 (dua) tahun. ${ }^{32} \mathrm{Hal}$ ini berbeda dengan ketentuan yang diatur dalam Pasal 42 ayat (1) UUJPH yang menentukan sertifikat halal yang dikeluarkan BPJPH berlaku selama 4 (empat) tahun. Adapun sertifikat halal wajib diperpanjang oleh pelaku usaha dengan mengajukan pembaruan sertifikat halal paling lambat 3 (tiga) bulan sebelum masa berlaku sertifikat halal berakhir.

Pengawasan dalam jaminan produk halal yang dilakukan oleh MUI meliputi pengawasan terhadap pelaku usaha (produsen), distribusi dan peredaran produk halal. Pengawasan yang selama ini dilakukan oleh MUI terbatas pada pengawasaaan terkait ketatan pelaku usaha (produsen) dalam menerapkan sistem jaminan halal. Selain itu pengawasan juga dilakukan secara parsial dan tempores melalui metode sampling. ${ }^{33}$ Lemahnya pengawasan banyak terjadi terkait dengan sertifiksi yang sudah kadaluarsa yang tidak memperjang sertifikasi halal serta pemalsuan logo halal. ${ }^{34}$

Praktik penyelenggaraan sertifikasi halal di Indonesia terkait dengan pemberlakuan UUJPH menentukan bahwa selama BPJPH belum terbentuk sertifikasi halal tetap dilaksanakan oleh LPPOMMUI. Penyelenggaraan sertifikasi halal yang dilaksanakan oleh LPPOM-MUI pada dasarnya bersifat tidak wajib. Pengaturan sertifikasi halal suati produk pada dasarnya merupakan kewajiban dari pelaku usaha apabila pelaku usaha mencantumkan label halal dalam kemasan produknya. Sertifikasi halal bagi pelaku usaha sebelum pemberlakuan UUJPH ini tidaklah diwajibkan bagi pelaku usaha. Obyek sertifikasi halal selama ini hanya tidak meliputi semua produk barang dan jasa, namun hanya dikhususkan pada produk barang. Kondisi demikian tentunya belum dapat memberikan kepastian hukum jaminan produk halal bagi konsumen muslim di Indonesia.

\section{Konsep Badan Penyelenggara Jaminan Produk Halal (BPJH) dalam Penyeleng- garaan Sertifikasi Halal di Indonesia}

Badan Penyelenggara Jaminan Produk Halal (BPJPH) merupakan lembaga yang akan dibentuk yang diberikan kewenangan untuk penyelenggaran jaminan produk halal di Indonesia. Tujuan dari penyelenggaraan jaminan produk halal yakni untuk memberikan kenyamanan, keamanan, keselamatan dan kepastian ketersediaan produk halal bagi masyarakat. BPJPH ini berkedudukan di bawah dan bertanggung jawab kepada Menteri Agama.

BPJPH dalam penyelenggaran jaminan produk halal memiliki kewenangan antara lain merumusan dan mentapkan jaminan produk halal, menetapkan norma, standar, prosedur dan

Majelis Ulama Indonesia, "Prosedur Sertifikasi Halal MUI", http://www.halalmui.org/muil4/index.php/main/go_to_section/56/1362/page/1, diakses 15 Mei 2015.

33 Majelis Ulama Indonesia, "Peranan MUI dalam Sertifikasi halal”, http://www.halalmui.org/newMUI/index.php/main/detil_page/8/1992, diakses 15 Mei 2015.

34 Husna Zahir, "YLKI : Harusnya MUI Perketas Pengawasan Sertifikasi Halal Kadaluarsa", http://nasional.republika.co.id/berita/nasional/ uтum/15/01/21/niibhh-ylki-harusnya-mui-perketat-pengawasan-sertifikat-halal-kedaluwarsa, diakses 24 Juni 2015. 
kriteria jaminan produk halal serta menerbitkan dan mencabut sertifikasi halal dan label halal. ${ }^{35}$ BPJPH dalam melaksanakan kewenangannya itu bekerjasama dengan kementerian dan/atau lembaga terkait, Majelis Ulama Indonesia (MUI) dan Lembaga Pemeriksa Halal (LPH).

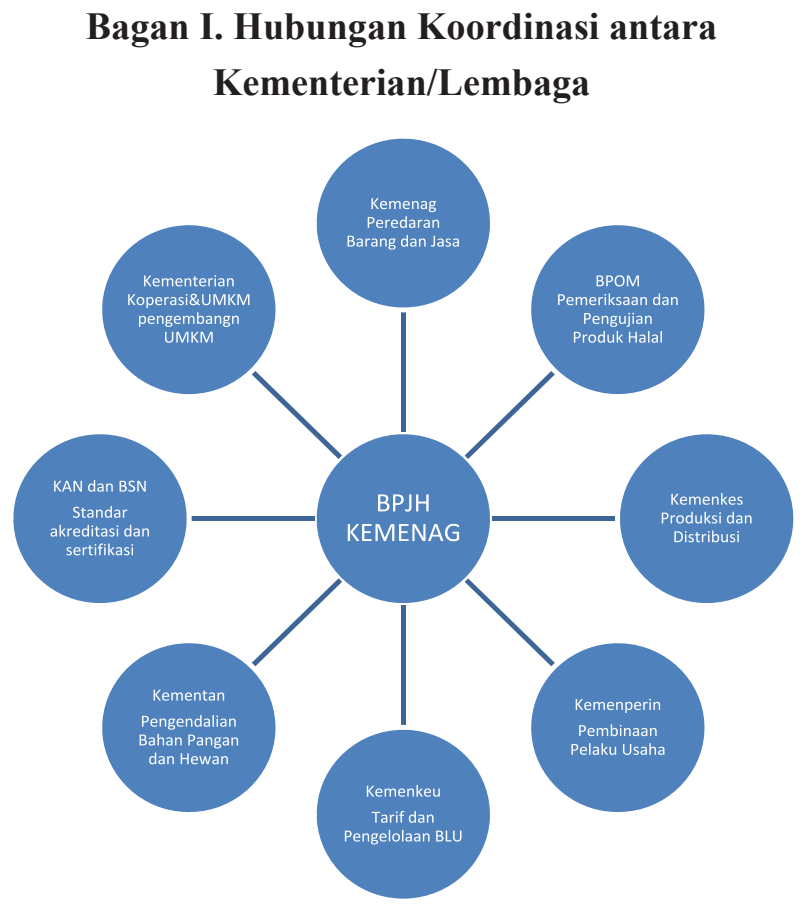

Sumber : Kementerian Agama, ${ }^{36} 2015$.

UUJPH terlahir sebagai upaya pemerintah dalam memberikan perlindungan kepada konsumen dalam menggunakan dan mengkonsumsi produk halal sesuai dengan ajaran agama Islam. Bahwa dalam penyelenggaran jaminan kehalalan dilaksanakan melalui proses yang panjang. Hal ini sesuai dengan Pasal 1 angka (3) UUJPH yang menentuka bahwa jaminan kehalalan suatu produk mencakup penyediaan bahan, pengolahan, penyimpanan, pengemasan, pendistribusiaan, penjualan dan penyajian dari produk tersebut. Sehingga dalam penyelenggaraan jaminana produk halal memerlukan kerjasama dan koordinasi dengan kementerian dan lembaga terkait. Kerjasama ini didasarkan kepada tugas, fungsi dan kewenangan yang dimiliki oleh kementerian dan lembaga terkait. Dengan adanya kerjasama dan koordinasi ini diharapkan penyelenggaraan jaminan produk halal dapat terlaksana.

Dalam bagan di atas dapat dijelaskan hubungan koordinasi dan kerjasama antara BPJPH yang ada di bawah Kementrian Agama dengan kementrian dan lembaga terkait. Adapun hubungan koordinasi dan kerjasama antara BPJPH dengan kementerian atau lembaga terkait adalah sebagai berikut: $^{37}$

\section{BPJPH dengan Kementerian Perda- gangan:}

Hubungan koordinasi BPJPH dengan Kementerian Perdagangan yakni terkait dengan Peredaran Barang dan Jasa. Pelaksana dalam kerjasama dengan Kementerian Perdagangan dalam hal ini adalah Direktorat Standarisasi dan Perlindungan Konsumen (Direktorat SPK). Direktorat SPK sebagai pihak yang memiliki kewenangan terkait dengan peredaran barang dan/atau jasa oleh pelaku usaha. Selain itu bentuk koordinasi dan kerjasama antara BPJPH dengan Kementerian Perdagangan yakni dalam hal menentukan kewajiban bagi para pelaku usaha yang ada di Indonesia maupun produk yang berasal dari luar negeri yang akan masuk ke Indonesia untuk melaksanakan sertifikasi dan labelisasi produk terkait dengan kehalalan suatu produk.

\section{BPJPH dengan Kementerian Kese- hatan: \\ Hubungan koordinasi BPJPH dengan} Kementerian Kesehatan yakni terkait dengan penetapan cara produksi dan distribusi terkait dengan obat-obatan, kosmetik dan alatalat keseahatan. Kerjasama BPJPH dengan Kementerian Kesehatan terkait dengan

\footnotetext{
Pasal 6 Undang-Undang No. 33 Tahun 2014 tentang Jaminan Produk Halal (Lembaran Negara Republik Indonesia Tahun 2014 Nomor 295, Tambahan Lembaran Negara Republik Indonesia Nomor 5604).

6 Wawancara dengan Nurgina Arsyad, Kasi Penyuluhan Produk halal, Kementerian Agama RI, 18 Mei 2015.

37 Ibid.
} 
pengawasan terhadap bahan obat-obatan dan alat-alat kesehatan.

\section{BPJPH dengan Badan Pengawas Obat dan Makanan (BPOM):}

Hubungan koordinasi BPJPH dengan Badan Pengawas Obat dan Makanan yakni terkait dengan pemeriksaan dan pengujian produk halal. Kerjasama yang dapat dilakukan terkait dengan kewenangan BPOM dalam pengawasan produk yang beredar di masyarakat. BPOM dapat melakukan pemerikasaan dan pengujian produk barang (makanan) yang telah beredar dimasyarakat baik yang sudah bersertifikasi halal maupun belum bersertifikasi halal. Pemeriksaan dan pengujian ini terkait kompisisi bahan yang terkandung dalam produk tersebut.

\section{BPJPH dengan Kementerian Perin-} dustrian:

Hubungan koordinasi BPJPH dengan Kementerian Perindustrian yakni terkait dengan pembinaan pelaku usaha. Kementerian Perindustrian dalam hal ini melakukan pembinaan kepada pelaku usaha terkait pengadaan bahan baku, proses produksi harus memenuhi standar dan ketentuan kehalalan suatu produk.

\section{BPJPH dengan Kementerian Ke- uangan:}

Hubungan koordinasi BPJPH dengan Kementerian Keuangan yakni terkait dengan penentuan tarif dan pengelolaan keuangan BPJPH sebagai Badan Layanan Umum (BLU). BPJPH sebagai BLU dalam penentuan tarif atau pemungutan dana dari masyarakat serta dalam pengelolaan keuangan harus berkoordinasi dengan Direktorat Jendral Perbendaharaan c.q. Direktorat Pembinaan Pengelolaan Keuangan Badan Layanan Umum (PPK-BLU). Ditjen Perbendaharaan c.q. Direktorat PPK-BLU dapat memberikan bimbingan, asistensi, dan konsultasi dalam penyusunan tarif/pola tarif dan menyampaikan rekomendasi kepada
Menteri Keuangan mengenai penetapan usulan tarif/ pola tarif.

\section{BPJHP dengan Kementerian Perta- nian: \\ Hubungan koordinasi BPJPH dengan} Kementerian Pertanian yakni terkait dengan pengendalian bahan pangan dan hewan. Tujuan dari pengendalian bahan pangan yaitu terkait dengan penggunaan zat-zat kimia produk pangan yang menggandung unsur yang tidak halal, antara lain misanya pemanfaatan vaksin zat-zat rekasaya genetika/ ilmu pengetahuan yang memungkinkan adanya pencampuran antara bahan yang halal dan yang tidak halal baik di sengaja maupun yang tidak disengaja. Adapun terkait pengendalian terhadap hewan dapat dilaksanakan terkait dengan pemiliharaan hewan yang menggunakan zat-zat atau vaksin yang belum jelas kehalalannya maupun dalam proses pemotongan di Rumah Potong Hewan harus memenuhi standar kehalalan.

\section{BPJPH dengan Komite Akreditasi} Nasional (KAN) dan Badan Standarisasi Nasional (BSN):

Hubungan koordinasi BPJPH dengan KAN dan BSN yakni terkait dengan standar akreditasi dan sertifikasi. Koordinasi terkait standarisasi kehalalan suatu produk dilakukan dalam rangka penyusunan standar akreditasi yang akan dilakukan oleh BPJPH maupun akreditasi terhadap LPH. Koordinasi penyusunan standarisasi prosedur/ proses sertifikasi halal, pelaksanaan akreditasi terhadap LPH diperlukan guna memenuhi standar yang telah di tentukan oleh BSN.

\section{BPJPH dengan Kementerian Kope- rasi dan UMKM:}

Hubungan koordinasi BPJPH dengan Kementerian Koperasi dan UMKM yakni terkait dengan pembinaan dan pengembangan UMKM. Maksud dari pembinaan dan pengembangan ini adalah memberikan kesadaran kepada pelaku usaha mengenai 
pentingnya sertifikasi halal suatu produk. Koordinasi juga terkait dengan fasilitasi kepada koperasi dan UMKM terkait dengan pembiayaan sertifikasi halal.

Bentuk kerjasama BPJPH dengan Majelis Ulama Indononesia (MUI) dalam penyelenggaran jaminan produk halal dilaksanakan dalam rangka sertifikasi Auditor Halal, penetapan fatwa halal, serta akreditasi terhadap Lembaga Pemeriksa Halal (LPH). MUI dalam menetapkan fatwa halal atas produk yang dimintakan sertfikasi halalnya kepada BPJPH, maka akan dilaksanakan sidang fatwa halal yang akan menghasilkan penetapan kehalalan suatu produk. Dalam sidang fatwa halal, MUI mengikutsertakan pakar, unsur kementerian dan lembaga terkait. Penetapan halal ini akan menjadi dasar BPJPH untuk penerbitan sertifikasi halal. ${ }^{38}$

Bentuk kerjasama BPJPH dengan Lembaga Pemeriksa Halal (LPH) dilaksanakan dalam rangka pemeriksaan dan pengujian produk. LPH sebelum diberikan kewenangan untuk melaksanakan pemeriksaan dan pengujian produk terlebih dahulu harus dilakukan akreditasi oleh BPJPH. Dalam pemeriksaan dan pengujuan produk oleh LPH, pemeriksaan dan pengujian dilaksanakan oleh auditor halal LPH.

Persoalan perlindungan konsumen muslim terkait dengan sertifikasi halal tidak hanya dilihat dalam kontek BPJPH saja. Namun dalam konteks penyelenggaraan sertifikasi halal ini harus juga dilihat keterkaitan dengan kementerian dan lembaga terkait. Persoalan penyelenggaran jaminan produk halal tidak semata membicarkan persoalan mengenenai sertifikasi halal saja, namun banyak hal yang terkait dengan penyelenggaran jaminan produk halal.

Penyelenggaraan jaminan produk perlu didukung dengan tindakan-tindakan persuasif maupun peningkatan kesadaran pelaku usaha mengenai pentingnya sertifikask halal, baik dari segi hak konsmen maupun dari segi pelaku usaha. Hal yang demikian tentunya membutuhkan sosialisasi kepada pelaku usaha dengan bantuan dari pihak kementerian terkait. Selain itu pada tahap pasca penerbitan sertifat halal perlu adanya pengawasan yang efektif agar menjamin ketaatan pelaku usaha. Pengawasan seperti ini akan lebih efektif dan efisien jika dilaksanakan dengan lembaga/ badan terkait.

Hubungan koordinasi dan kerjasama atara BPJPH dengan kementerian dan lembaga terkait tugas, fungsi dan kewenangan yang dimiliki oleh kementerian dan lembaga terkait. Dalam beberapa hal BPJPH dapat melaksanakan koordinasi dan kerjasama berkaitan dengan penyelenggaraan jaminan produk halal. Hal ini dapat dilaksanakan dengan cara mensinergikan tugas, fungsi dan kewenangan kementerian dan lembaga terkait dengan kewenangan yang dimiliki oleh BPJPH. Upayaupaya ini perlu ditempuh untuk mewujudkan tujuan dari penyelenggaraan jaminan produk halal yakni memberikan kenyamanan, keamanan, keselamatan dan kepastian ketersedian produk halal bagi masyarakat dalam mengkonsumsi dan menggunakan produk. Selain itu, juga dapat meningkatkan nilai tambah bagi pelaku usaha untuk memproduksi dan menjual produk halal. Penyelengaraan jaminan produk halal oleh BPJPH yang efektif dan efesien tentunya akan berimbas kepada meninggkatnya perlindungan terhadap konsumen, terutama bagi konsumen muslim. Dengan demikian tujuan dari perlindungan konsumen dapat tercapai.

\section{Kesimpulan}

Berdasarkan hasil penelitian dan pembahasan yang telah diuraikan di atas diperoleh kesimpulan yakni, Pertama selama BPJPH belum terbentuk sertifikasi halal tetap dilaksanakan oleh LPPOMMUI. Praktik penyelenggaran sertifikasi halal oleh LPOM-MUI bersifat sukarela, sehingga sertifikasi halal sangat tergantung kepada itikad baik pelaku usaha. Hal ini menyebabkan tidak semua produk tersertifikasi, sehingga belum memberikan kepastian hukum jaminan produk halal bagi konsumen muslim. BPJPH dalam pelaksanaan 
sertifikasi halal bekerjasama dengan MUI dan LPH. BPJPH dalam penyelenggaraan jaminan produk halal perlu mensinergikan kewenangan yang dimilikinya dengan tugas, fungsi dan kewenangan kementerian dan lembaga terkait. Sinergi tugas, fungsi dan kewenangan BPJH dengan kementerian dan lembaga terkait mulai dari sebelum proses sertifikasi sampai dengan pengawasan terhadap jaminan produk halal.

\section{DAFTAR PUSTAKA}

\section{A. Buku}

Mertokusumo, Sudikno, 2006, Penemuan Hukum : Sebuah Pengantar, Liberty, Yogyakarta.

Shidarta, 2004, Hukum Perlindungan Konsumen, Gramedia, Jakarta.

Sidabalok Janus, 2006, Hukum Perlindungan Konsumen di Indonesia, Citra Aditya Bakti, Bandung.

Soemitro, Ronny Hanitijo, 1990, Metodologi Penelitian Hukum dan Jurimetri, Ghalia Indonesia, Jakarta.

Soekanto, Soerjono, et al., 2006, Penelitian Hukum Normatif suatu Tinjauan Singkat, Rajawali, Jakarta.

Sumadi, 1988, Metode Penelitian, Rajawali, Jakarta.

\section{B. Artikel dalam Jurnal}

Hasan, KN. Sofyan, "Kepastian Hukum Sertifikasi dan Labelisasi Halal Produk Pangan", Dinamika Hukum, Vol. 14, No. 2, Mei 2014.

Rosidah, Zaidah Nur, "Sinkronisasi Peraturan Perundang-Undangan Mengenai Perkawinan Beda Agama", Al-Ahkam,Vol. 23, Nomor 1, April, 2013.

\section{Internet}

Hantoro,NoviantoM., "SinkronisasidanHarmonisasi Pengaturan Mengenai Peraturan Daerah, Serta Uji Materi Peraturan Daerah Provinsi Bali Nomor 16 Tahun 2009 Tentang Rencana Tata Ruang Wilayah Provinsi Bali Tahun 2009-2029", http://perpustakaan.bappenas. go.id/lontar/file?file = digital/130881 $\% 5 B \_K o n t e n \_\% 5 D-K o n t e n \% 20 C 9218 . p d f$, diakses 21 September 2015.
Husna Zahir, "YLKI : Harusnya MUI Perketas Pengawasan Sertifikasi Halal Kadaluarsa", http://nasional.republika.co.id/berita/ nasional/umum/15/01/21/niibhh-ylkiharusnya-mui-perketat-pengawasansertifikat-halal-kedaluwarsa, diakses 24 Juni 2015.

Mahendra, AA. Oka, "Harmonisasi Peraturan Perundang-undangan", http://ditjenpp. kemenkumham.go.id/htn-dan-puu/421harmonisasi-peraturan-perundangundangan.html, diakses 14 Agustus 2015.

Majelis Ulama Indonesia, "Tentang LPPOM-MUI", http://www.halalmui.org/muil4/index.php/ main/go_to_section/2/31/page/1, diakses 15 Mei 2015.

Majelis Ulama Indonesia, "Sertifikat Halal MUI", http://www.halalmui.org/muil4/index.php/ main/go_to_section/55/1360/page/1, diakses 15 Mei 2015.

Majelis Ulama Indonesia, Tentang LPPOMMUI",http://www.halalmui.org/mui14/ index.php/main/go_to_section/2/31/page/1 diakses 15 Mei 2015.

Majelis Ulama Indonesia, "Persyaratan Sertifikasi Halal MUI", http://www.halalmui.org/muil4/ index.php/main/go_to_section/58/1366/ page/1 diakses 15 Mei 2015.

Majelis Ulama Indonesia, "Prosedur Sertifikasi Halal MUI", http://www.halalmui.org/mui14/ index.php/main/go_to_section/56/1362/ page/l, diakses 15 Mei 2015.

Majelis Ulama Indonesia, "Peranan MUI dalam Sertifikasi halal", http://www.halalmui.org/ newMUI/index.php/main/detil_page/8/1992, diakses 15 Mei 2015. 
Nonako, Ryo, "Jepang Lebih Peduli Produk Halal", http://www.pikiran-rakyat.com/ ekonomi/2015/03/17/320203/jepang-lebihpeduli-produk-halal, diakses 22 Juni 2015.

\section{Peraturan Perundang-undangan}

Undang-Undang No. 8 Tahun 1999 Tentang Perlindungan Konsumen (Lembaran Negara Republik Indonesia Tahun 1999 Nomor 42, Tambahan Lembaran Negara Republik Indonesia Nomor 3821).

Undang-Undang No. 33 Tahun 2014 tentang Jaminan Produk Halal (Lembaran Negara
Republik Indonesia Tahun 2014 Nomor 295, Tambahan Lembaran Negara Republik Indonesia Nomor 5604).

Peraturan Pemerintah No. 69 Tahun 1999 tentang Label dan Iklan Pangan (Lembaran Negara Republik Indonesia Tahun 1999 Nomor 131, Tambahan Lembaran Negara Republik Indonesia Nomor 3867).

\section{E. Lain- Lain}

Wawancara dengan Nurgina Arsyad, Kasi Penyuluhan Produk halal, Kementerian Agama RI, 18 Mei 2015. 